\title{
THE PEDAGOGICAL SIGNIFICANCE OF THE WORK OF MODERN UZBEK COMPOSERS
}

\section{Abdupatto Ahmadjonovich Ibragimov}

Head of The Department Of Music Education, Namangan State University, Uzbekistan

Konstantin Konstantinovich Shalankov

Master, Namangan State University, Uzbekistan

Fatima Yaqubjon Kizi Jumanazarova

Master, Namangan State University, Uzbekistan

\section{ABSTRACT}

The development of culture and art in our society is based on specific trends. In this regard, music culture has entered an important stage of development, which contributes to the growth of spiritual and cultural consciousness of the people. earns. The teacher-student tradition is unique to our nation and is still used in practice by many master artists.

KEYWORDS: - Teacher, student, national, creativity, music, tradition, education, melody, culture.

\section{INTRODUCTION}

After Uzbekistan gained independence, obstacles to the development of national music were removed. This is the art of singing, in general, not a denial of democratic principles in our national culture, but rather a state of protection of national interests. However, at the same time there are a number of problems in this regard. Under the slogan of freedom, there is a growing number of seasonal songs that do not meet the ideological and moral requirements. The lack of juice in music, poetry, or performance is fueling open protests.[1]

In this sense, we offer:

1. The development of the art of music depends more on solving the problem of repertoire. This is a very necessary issue. After all, in the context of the transition of society from one qualitative stage to another, ignoring it creates a sense of belonging in art. Therefore, it is necessary to address the issue of strengthening the independence of the Ministry of Culture and Sports of the Republic of Uzbekistan, regional departments of culture and sports, increasing the responsibility of the Uzbeknavo variety ensemble 
CURRENT RESEARCH JOURNAL OF PEDAGOGICS 2(12): 77-81, December

2021 DOI: https://doi.org/10.37547/pedagogics-crjp-02-12-16

ISSN 2767-3278

(C)2021 Master Journals

\section{Crossref do) 8 Google}

Accepted 18 ${ }^{\text {th }}$ December, 2021 \& Published 23 ${ }^{\text {th }}$ December, 2021

in working with the repertoire, inculcating the idea of national independence in the minds and hearts of the general public.

2. An important factor in the development of the art of music is also associated with the training of highly qualified personnel. Higher education institutions that train personnel in the field of culture and arts, in particular, the faculty of music education of the State Conservatory of Uzbekistan, faculty of "Art" of Tashkent State Pedagogical University named after Nizami, should also make a significant contribution in this regard. To this end, we consider it appropriate to revise the admission procedure and admission plan for gifted students.

3. The development of music in Uzbekistan largely depends on the quality and effectiveness of "Music Culture" lessons in secondary schools and folk amateur art. Because the foundation of music education starts here. Hundreds of amateur art groups in our country, its participants are an important source for the development of professional singing. In this regard, it is important to support young talents, amateur artists, provide them with material, spiritual and creative care, as well as to encourage their work.

4. A strong process of liberalization is taking place in the spiritual and enlightenment sphere. Barriers to repertoire have been removed. As a result, the artist had the opportunity to create freely. But that shouldn't allow the creator to do what he wants. While non-national "songs" in the tone of music are, on the one hand, shallowing our spiritual life, on the other hand, people are in a state of adornment from such "art". In our opinion, in order to further develop our modern art of singing, its role and importance in the life of society, in the upbringing of a harmoniously developed generation, in increasing the spiritual wealth of people, officials should strengthen their responsibility.
5. The development of music in Uzbekistan depends on the level of in-depth and comprehensive study of the history and theory of this field. In our opinion, little attention is paid to this issue. Therefore, we believe that the solution of the problem of scientific research of the art of singing, both theoretically and historically, at the Research Institute of Art History of the Academy of Arts of Uzbekistan will give positive results. In his book "High spirituality is an invincible force", the First President of the Republic of Uzbekistan I. Karimov analyzed the development of our musical culture today and its role in the life of society and identified further tasks. "When we talk about the spiritual maturity of a person, of course, this goal cannot be achieved without the art of music. Music has always played a unique role in the life of our people. This is evidenced by the discovery of a bone flute 3,300 years ago in the village of Muminabad near Samarkand. We need to inculcate this truth in the minds of our citizens, especially our youth. [2]

Because there were three truth lessons in this place. These are:

1. Music culture plays an important role in the spiritual development of a person.

2. Our people have been acquainted with musical culture for centuries.

3. There is a lot of evidence to prove this point. For almost three and a half years, our musical culture has been educating a whole generation as moral, strong and courageous people. Moreover, the fact that our musical culture has such a long history also shows that our people have unique talents and abilities. A nation with such a culture knows that kindness, tolerance and creativity are primary. In this regard, the head of state quotes from the book "Zafarnoma" by historian Sharofiddin Ali Yazdi about the development of music culture in the time of Amir Temur. Because our ancestor Temur and his descendants were well aware of the importance of music culture in 
CURRENT RESEARCH JOURNAL OF PEDAGOGICS 2(12): 77-81, December

2021 DOI: https://doi.org/10.37547/pedagogics-crjp-02-12-16

ISSN 2767-3278

(C)2021 Master Journals

Crossref do: 81 Google

Accepted $18^{\text {th }}$ December, 2021 \& Published 23 th December, 2021

the development of society, Zahiriddin Muhammad Babur wrote about this issue in detail in his work "Boburnoma".

During the years of independence, this glorious tradition was continued on a modern basis. As noted by the head of state, "During the years of independence, programs and plans are being implemented in our country, which continue the traditions of our great ancestors and are aimed at the development of music in our country". Among them is the Resolution of the First President of the Republic of Uzbekistan IA Karimov "On the development of children's music and art schools and strengthening the material and technical base". According to him, in 2009-2014, children's music and art schools will be radically reformed. It should be noted that this program is the only one in Central Asia.

Today, the development of our musical culture is carried out in four directions:

- Preservation and study of our classical musical heritage;

- Formation of musical culture in the minds of the younger generation;

- Encouraging talented people through prestigious competitions and international conferences;

- $\quad$ Training of national staff. [3]

Modern music can be conditionally divided into serious and light types of music according to its ideological content and artistic expression. By "light music" we mean popular melodies - songs and pop, rock, rap and jazz music. By "serious music" we mean classical music, especially serious works in major genres. The meaning of seriousness in music - style, genre and its form regardless of size, is expressed in important social themes, deep philosophical ideas, freedom and happiness - the struggle for happiness, the pain of first love, deep human feelings. It has a profound emotional impact on the listener and encourages him to think seriously. Music created in the past, which has become classical and has not lost its artistic essence, is understood today, and music that delights mankind is also modern. Although the maqams, which were the spiritual pride of our people in the past, were created centuries ago, they still amaze our listeners with the beauty and perfection of their words. For this reason, among our people, classical works such as maqoms, shashmaqoms, big songs are ancient and still young. Proof of this can be seen in the music of the great German composer I.S. Bach, who lived and worked two and a half years ago. In particular, the fine art of I.S. Bach reflects deeply on the happiness and death of human life, which in turn has always been a topical issue for humanity.

The concept of modern music belongs only to the genre of polyphonic music, and also applies to the work of traditional composers, who are developing in new ways in accordance with the new generation. Today, the requirements of modern music are to be independent in every field, to restore our national values and to operate within world standards. We see this in the rapid development of the art of music and in the widespread use of forms of popular music among our people. It should be noted that in our music, universal musical forms, imbued with the spirit of the times, are developing and enriching the original with modern secular genres. The independence of the Republic of Uzbekistan has opened wide opportunities for the development of national forms of education. The theory of national education used the sciences of philosophy, pedagogy, psychology, music, sophistication, and fine arts to substantiate its rules. [4]

You will be amazed every time you listen to the magical statues created by the great genius of the people and polished for centuries, the unique musical works that testify to the amazing talent of our composers. These melodies penetrate into 
CURRENT RESEARCH JOURNAL OF PEDAGOGICS 2(12): 77-81, December

2021 DOI: https://doi.org/10.37547/pedagogics-crjp-02-12-16

ISSN 2767-3278

(C)2021 Master Journals

\section{Crossref do) 8 Google}

Accepted $18^{\text {th }}$ December, 2021 \& Published 23 th December, 2021

the depths of the listener's heart, brighten the emotions in the seven colors of the rainbow, inviting the listener to the boundless world of musical sounds, sometimes pure, sometimes sad.

When our souls, which are usually moved by such eternal works of art, come to their senses, we want to know who their creators are, in what situation, under the influence of life events, for many years, for centuries, what great talents, in what words, how they performed.

When our great ancestor Abu Nasr al-Farabi finished his Risalai Musiqa, he said, 0 Alhazar, 0 world of music, it is better for you to go. he exclaimed, speaking to the hearts of generations to come.

When you think about it, true music, singing, devotion to art is a miraculous power that gives a person an unbreakable wing, takes him across the borders of centuries and distances, and makes him dependent on eternity. Music culture inspires society, inspires people, encourages them to higher ideals. Therefore, the First President of the Republic of Uzbekistan I. Karimov emphasizes this fact: "We all know that the love of music, art, music culture is formed in our people from childhood, in the family. It is no exaggeration to say that it is difficult to find in our country a person who does not have a dutar, a doira or any other instrument at home, and who does not feel the life-giving effects of music in his life. " Indeed, this national tradition fully reflects the talent, intelligence and ability of our people. "The most important thing," said I. Karimov, "is that today the art of music has a greater and stronger impact on the development of our young generation in the spirit of high spirituality than any other art form." So, we need to focus on the perfection of music today and what kind of music young people are listening to. Because these two issues are very important and are related to the spiritual consciousness of man. It is important not to present light melodies as melodies, but to make young people listen to the best music. In this regard, the head of our state emphasizes the masterpiece "Shashmaqom" and the works of Mozart, Beethoven, Bach and Tchaikovsky. This guide should serve as a guide for staff working in the field of culture and the arts. Because in this regard, the Head of State is based on the following two criteria:

1. "If a person's ear becomes accustomed to light, dull tones, it is possible that his artistic taste, his musical culture will gradually decline, and his spiritual world will be taken over by false notions. "So it's time to stop offering nonsensical "music" to people, especially young people.

2. "The sounds of music, regardless of the performance of any people or nation, express the most noble, lofty and delicate human experiences". So, the effective use of national and universal musical heritage will bring our people to spiritual heights.

While analyzing the issue of our musical culture and its role in the development of society, the head of state spoke about the national pop art, which is an integral part of our culture. An interesting fact is noted: "It can be said that the Uzbek pop music, whose first samples appeared at the beginning of the last century, has reached a qualitatively new level during the years of independence". Indeed, there are reports that in the early twentieth century, the cornerstone of our national pop art was laid by Jadid thinkers. Fitrat, for example, speaks of this in his works, and the Jadids sought to introduce cheerful and playful melodies into practice. Because such songs inspired people. In this sense, our national pop art has a hundred-year history. [5]

Indeed, during the years of independence, our national pop art has reached a new level. These are as follows:

- to study the achievements of national and universal music; 
CURRENT RESEARCH JOURNAL OF PEDAGOGICS 2(12): 77-81, December

2021 DOI: https://doi.org/10.37547/pedagogics-crjp-02-12-16

ISSN 2767-3278

(C)2021 Master Journals

Crossref doi) 81 Google

Accepted $18^{\text {th }}$ December, 2021 \& Published 23 th December, 2021

- Enjoy the best examples of world pop music;

- creating favorable conditions for young talents;

- For the first time in the history of our musical culture began training in the field of national variety.

There are also problems in the development of our national pop art, which is an integral part of our musical culture. The head of state highlighted three such issues as follows:

1. When we talk about the current and future development of pop art, it is natural to pay special attention to the meaning of the term national variety, to protect it from any foreign influences, especially from the influence of" popular culture . Indeed, national pop music is a set of meaningful music, meaningful singing and moral behavior. [6]

2. The "works" presented to the public by some young performers and creative groups do not meet any of the requirements and criteria of art. Not only the theme and the music, the methods of performance, but also the imitation of foreign "popular culture" in the stage movements, the frequent occurrence of "stellar" diseases, will certainly upset real art fans. This issue should be considered by experts and the public. We need to save young talents from these vices. [7]

3. "I think that some young performers consider inappropriate actions, such as music videos, mixing words in different languages or deliberately distorting pronunciation, which do not comply with our national traditions and morals, as a new style for themselves, but not understanding art, its essence and significance. not ". The truth is that such a flaw hinders the development of our national variety. Many of our performers are not ashamed to talk about the cultural level of their product, but about how much money they have spent on it.
1. Rajabov I. On the issue of status. Tashkent. 1963. - P. 20.

2. Fitrat A. Uzbek classical music and its history. Tashkent. 1993. - P.52.

3. Rajabov A. Namai Niyogon. Dushanbe. Irfon.1988. - P.26.

4. Fitrat A.Uzbek classical music and its history. Tashkent 1993. - P. 10.

5. Odilov A., Lutfullaev A. Chang. Tashkent. 2002.- P.85.

6. Abdullaeva C. Narodnie muzikalnie instrumenti Azerbaydjana. Baku. 1972.- P.63.

7. Karomatov F. Uzbek instrumental music. Tashkent. 1972. - P. 52

\section{References}

